\title{
Reviewer Capital: Hidden intangible resources
}

\author{
Thomas W. Günther ${ }^{1}$
}

Published online: 10 February 2016

(C) Springer-Verlag Berlin Heidelberg 2016

An academic journal, such as the Journal of Management Control, is a complex network of different stakeholders. One of the major stakeholder groups are reviewers. Running an academic journal without the support of reviewers would not be possible.

From my personal point of view, reviewers represent a hidden intangible resource. Following Barney (2001) resources have to fulfill the VRINE criteria to be a significant and sustainable competitive advantage. They have to be valuable, rare, imperfectly imitable, not substitutable and exploitable. All these criteria hold for the reviewers of the Journal of Management Control. However, I hope that we do not exploit our reviewers to much. At least, we hope so and we by nature understand if a reviewer rejects our invitation to review because of time constraints.

We all should be aware that accepting a review often implies for a reviewer investing "nights and weekends" in something he is not paid for and in something he often is not honoured for in times of prevalently too much overall workload. Nevertheless, we appre-ciate very much the expertise offered for free, often recommendations filling pages to guide the author(s) to improve their paper and for their transfer of knowledge and experi-ence in academic research. The editors of the Journal of Management Control are infi-nitely grateful for this voluntary support of our journal.

On the one hand, providing reviews should be honoured more extensively by the heads of schools and departments in the performance measurement of colleagues. Inviting some-body to review a paper implies also honouring his expertise and experience in academic research. On the other hand, writing an excellent review induces also contributions to our academic profession as scholars. A higher education institution is not comparable to a for-profit organisation run and organized by managerialism.

\footnotetext{
$凶$ Thomas W. Günther

thomas.guenther@tu-dresden.de

1 Journal of Management Control, Technische Universität Dresden, 01062 Dresden, Germany
} 
Researchers and teachers often understand themselves as part of a scientific community. Thus, supporting other scholars with our expertise and peer reviews is a vehicle to improve research outcome. Besides being an honour for the reviewer to be invited, the invitation can be also seen as a duty for all of us to contribute to the further development of our research field and of our academic profession. The editors of JoMaC get not seldomly very positive feedback es-pecially from younger scholar praising constructive and helpful recommendations from reviewers, which provide new insights and guidance to further develop their papers.

However, all of us taking part in the international competition to get our papers published also have personal experiences on "poor" reviews, which are too short, too superficial, criticizing that something is missing without giving recommendations for authors what to do, based on subjective non-substantial argumentation etc. It is our duty as editors to avoid this, first, by a good selection of international and experienced scholars, who have a good track record of high-level publications, who are experienced in specific methods and/or theoretical foundations, but who are also warm-hearted enough to give good guid-ance and helpful judgement and who are also open for new ideas to expand their own horizon.

This may sound idealistic and theoretical. However, for each paper it has to be decided on a day to day basis how to further proceed, and which is actually a lot of work for both reviewers and editors. Therefore, the editors of the Journal of Management Control appreciate very much the great and voluntary support of a large community of reviewers, which gets more and more international.

In 2015, the following reviewers in alphabetical order gave us their honour, dedicated their precious time for our papers and supported us with their expertise and judgement. We are unbelievable thankful for this great resource of reviewers of the Journal of Management Control (reviews finished in 2015):

\begin{tabular}{|c|c|c|c|}
\hline Title & Last name & First name & Affiliations \\
\hline Prof. Dr. & Aktas & Nihat & WHU-Otto Beisheim School of Management, Germany \\
\hline Prof. Dr. & Bassen & Alexander & University of Hamburg, Germany \\
\hline Dr. & Bedford & David & University of Technology Sydney, Australia \\
\hline Prof. Dr. & Berens & Wolfgang & University of Muenster, Germany \\
\hline Prof. & Bisbe Vinas & Josep & ESADE, Spain \\
\hline Prof. & Bjornenak & Trond & Norwegian School of Economics, Norway \\
\hline Dr. & Brauneis & Alexander & University of Klagenfurt, Austria \\
\hline Prof. & Brown & David A. & University of Technology Sydney, Australia \\
\hline Prof. Dr. & Brueggen & Alexander & Maastricht University, The Netherlands \\
\hline Dr. & Dang & David & Ivey Business School, Canada \\
\hline Dr. & Derfuß & Klaus & FernUniversität Hagen, Germany \\
\hline Prof. Dr. & Dinh & Tami & University of St. Gallen, Switzerland \\
\hline Jun-Prof. Dr. & Duchek & Stephanie & TU Dresden, Germany \\
\hline Dr. & Endrikat & Jan & TU Dresden, Germany \\
\hline Jun.-Prof. Dr. & Fourné & Sebastian & WHU-Otto Beisheim School of Management, Germany \\
\hline Prof. Dr. & Freidank & Carl-Christian & University of Hamburg, Germany \\
\hline Prof. Dr. & Fried & Andrea & Technische Universität Chemnitz, Germany \\
\hline Prof. Dr. & Gleich & Ronald & EBS Business School, Germany \\
\hline Prof. Dr. & Goretzki & Lukas & University of Innsbruck, Austra \\
\hline Prof. Dr. & Götze & Uwe & Technische Universität Chemnitz, Germany \\
\hline
\end{tabular}




\begin{tabular}{|c|c|c|c|}
\hline Title & Last name & First name & Affiliations \\
\hline Prof. Dr. & Grössler & Andreas & Radboud University, The Netherlands \\
\hline Prof. Dr. & Günther & Thomas & TU Dresden, GErmany \\
\hline Prof. Dr. & Helm & Roland & University of Regensburg, Germany \\
\hline Dr. & Heyden & Mariano & University of Newcastle, Australia \\
\hline Prof. Dr. & Hiebl & Martin & University of Siegen, GErmany \\
\hline Prof. Dr. & Hilbert & Andreas & TU Dresden, Germany \\
\hline Prof. Dr. & Hirsch & Bernhard & Universität der Bundeswehr München, Germany \\
\hline Prof. Dr. & Hitz & Jörg-Markus & Georg-August-Universität Göttingen, Germany \\
\hline Prof. & Holm & Morten & Copenhagen Business School, Danmark \\
\hline Prof. & Hommel & Ulrich & EBS Business School, Germany \\
\hline Prof. & Järvenpää & Marko & University of Jyväskylä, Finland \\
\hline Prof. Dr. & Knauer & Thorsten & University of Bayreuth, Germany \\
\hline Dr. & Kramer & Stephan & RSM Erasmus University, The Netherlands \\
\hline Prof. Dr. & Lachmann & Maik & TU Berlin, Germany \\
\hline Prof. & Laitinen & Erkki & University of Vaasa, Finland \\
\hline Dr. & Leitner & Stephan & Alpen-Adria Universität Klagenfurt, Austria \\
\hline Prof. Dr. & Letmathe & Peter & RWTH Aachen, Germany \\
\hline Prof. Dr. & $\mathrm{Li}$ & Frank & Richard Ivey School of Business, Canada \\
\hline Dr. & Linnenluecke & Martina & UQ Business School, Australia \\
\hline Dr. & Löffler & Clemens & University of Vienna, Austria \\
\hline Prof. & Madini & Paola Maria & ESADE, Spain \\
\hline Prof. Dr. & Mahlendorf & Matthias & $\begin{array}{l}\text { Frankfurt School of Finance and Management, } \\
\text { Germany }\end{array}$ \\
\hline Dr. & Malagueno & Ricardo & University of East Anglia, UK \\
\hline Prof. Dr. & Meckl & Reinhard & University of Bayreuth, Germany \\
\hline Prof. Dr. & Messner & Martin & University of Innsbruck, Austria \\
\hline Prof. Dr. & Meyer & Matthias & TU Hamburg-Harburg, Germany \\
\hline Prof. Dr. & Mödritscher & Gernot & Alpen-Adria-Universität Klagenfurt, Austria \\
\hline Prof. Dr. & Möller & Klaus & Universität St. Gallen, Switzerland \\
\hline Dr. & Moretti & Anna & University of Venice, Italy \\
\hline Prof. Dr. & Nevries & Pascal & University of Kassel, Germany \\
\hline Dr. & Nienhaus & Martin & University of Muenster, Germany \\
\hline Jun.-Prof. Dr. & Ott & Christian & $\begin{array}{l}\text { Europa-Universität Viadrina Frankfurt/Oder, } \\
\text { Germany }\end{array}$ \\
\hline Prof. & Parpinel & Francesca & University of Venice, Italy \\
\hline Prof. & Pellinen & Jukka & University of Jyväskylä, Finland \\
\hline Prof. & Pellizzari & Paolo & University of Venice, Italy \\
\hline Prof. Dr. & Pfeiffer & Thomas & University of Vienna, Austria \\
\hline Prof. & Provenzano & Davide & University of Palermo, Italy \\
\hline Dr. & Quinn & Martin & Dublin City University, Ireland \\
\hline Jun.-Prof. Dr. & Reimer & Marko & $\begin{array}{l}\text { WHU-Otto Beisheim School of Management, } \\
\text { Germany }\end{array}$ \\
\hline Prof. Dr. & Rohlfing-Bastian & Anna & University of Tuebingen, Germany \\
\hline Prof. Dr. & Scheytt & Tobias & Helmut-Schmidt University, Germany \\
\hline Prof. Dr. & Schiemann & Frank & University of Hamburg, Germany \\
\hline Prof. Dr. & Schöndube-Pirchegger & Barbara & $\begin{array}{l}\text { Otto-von-Guericke-University Magdeburg, } \\
\text { Germany }\end{array}$ \\
\hline Dr. & Schrack & Daniela & Johannes Kepler University Linz, Austria \\
\hline Dr. & Sommer & Friedrich & $\begin{array}{l}\text { Westfaelische Wilhelms-Universitaet Münster, } \\
\text { Germany }\end{array}$ \\
\hline Prof. Dr. & Strauss & Erik & Universitaet Witten/Herdecke, Germany \\
\hline Prof. & Teglio & Andrea & University Jaume, Spain \\
\hline Mr. & Sandelin & Mikko & Aalto University, Finland \\
\hline
\end{tabular}




\begin{tabular}{|c|c|c|c|}
\hline Title & Last name & First name & Affiliations \\
\hline Prof. Dr. & Schaeffer & Utz & $\begin{array}{l}\text { WHU-Otto Beisheim School of Management, } \\
\text { Germany }\end{array}$ \\
\hline Prof. Dr. & Troitzsch & Klaus & University of Koblenz-Landau, Germany \\
\hline Dr. & Ullmann & Robert & University of Muenster, Germany \\
\hline Dr. & van Doorn & Sebastiaan & University of Warwick, UK \\
\hline Prof. Dr. & Wall & Friederike & Alpen-Adria-University Klagenfurt, Austria \\
\hline Prof. Dr. & Wallenburg & Carl Marcus & $\begin{array}{l}\text { WHU-Otto Beisheim School of Management, } \\
\text { Germany }\end{array}$ \\
\hline Prof. Dr. & Weissenberger & Barbara & Heinrich Heine University Düsseldorf, Germany \\
\hline PD Dr. & Wöhrmann & Arnt & University of Muenster, Germany \\
\hline Prof. Dr. & Wömpener & Andreas & University of Duisburg-Essen, Germany \\
\hline
\end{tabular}

In 2016, two special issues on interesting topics will be published:

Middle managers in the strategy process, guest-edited by Marko Reimer, WHU Otto-Beisheim School of Management, Vallendar, Germany; Mariano L.M. Hey-den, University of Newcastle, Australia and Sebastiaan van Doorn, Warwick University, UK.

Innovation and management control, guest-edited by Uwe Götze, Technische Universität Chemnitz, Germany; Andrea Fried, Linköping University, Sweden; Klaus Möller, Universität St. Gallen, Switzerland and Paulo Peças, PhD, Universidade de Lisboa, Portugal.

The articles in this first issue of 2016 reflect the diversity of management control re-search. Andreas Wald and Jürgen Harrer explore the management control of enterprise security, a field that is heavily under researched in management control literature so far. The authors present a study based on qualitative interviews with security experts of German DAX 30-firms supplemented by a standardized survey. They examine the management control based on the Levers of Control Framework of Simons (1995).

With a cross-sectional analysis of 139 Japanese manufacturing firms Kimitaka Nishitani, Katsuhiko Kokubu and Takehisa Kajiwara analyse using regression modelling whether low carbon supply chain management in addition to an environmental management system (EMS) decreases GHG emissions and thus has an impact on the carbon productivity of their firm.

The qualitative approaches of business modelling, which are currently available, fall short of providing sound guidelines especially in uncertain, highly volatile situations. Stefan Grösser und Niklas Jovy use a quantitative approach founded on a systemic simulation methodology, which enables decision makers to obtain insightful experimental designs with a company's business modell. The authors use a case study of the e-commerce business to present their methodology and discuss advantages and disad-vantages of computational modelling as a strategy and management tool.

Finally, Jürgen Strohhecker examines whether factors such as a balanced scorecard (BSC) cockpit, intelligence, and knowledge explain differences in strategy implementation success. He uses a computer-based, feedback-rich system dynamics business game where participants were placed in a top manager position with two groups, one with a BSC management cockpit and the other as a control group with traditional information. His paper examines the differences between the two experimental groups. 


\section{References}

Barney, J. B. (2001). Is the resource-based "view" a useful perspective for strategic management research? Yes, Academy of Management Review, 26(1), 41-56.

Simons, R. (1995). Levers of control-how managers use innovative control systems to drive strategic renewal. Boston: Harvard Business School Press. 